\title{
RED BLOOD CELL ACETYLCHOLINESTERASE AND PLASMA BUTYRYLCHOLINESTERASE STATUS: IMPORTANT INDICATORS FOR THE TREATMENT OF PATIENTS POISONED BY ORGANOPHOSPHORUS COMPOUINDS*
}

\author{
Horst THIERMANN ${ }^{1}$, Kai KEHE ${ }^{1}$, Dirk STEINRITZ ${ }^{1}$, John MIKLER², Ira HILL², \\ Thomas ZILKER ${ }^{3}$, Peter EYER ${ }^{4}$, and Franz WOREK ${ }^{1}$ \\ Bundeswehr Institute of Pharmacology and Toxicology, Munich, Germany ${ }^{1}$, Casualty \\ Management Section, Defence Research and Development, Suffield, Canada ${ }^{2}$, Toxicological \\ Departments, $2^{\text {nd }}$ Medical Clinic, Technical University, Munich, Germany ${ }^{3}$, \\ Walther-Straub-Institute of Pharmacology and Toxicology, Munich, Germany ${ }^{4}$ \\ Received in August 2007 \\ Accepted in September 2007

\begin{abstract}
Inhibition of acetylcholinesterase (AChE) is regarded as the primary toxic mechanism of organophosphorus compounds (OP). Therapeutic strategies are directed to antagonise overstimulation of muscarinic receptors with atropine and to reactivate inhibited $\mathrm{AChE}$ with oximes. Reactivation is crucial within the neuromuscular synapse, where atropine is ineffective, since peripheral neuromuscular block eventually leads to respiratory failure. Patients with OP intoxication have to be identified as early as possible.

During an international NBC-defence exercise anesthetised pigs were poisoned with sarin, followed by treatment with atropine and oxime. Blood samples were drawn and red blood cell (RBC)-AChE activity determined with a fielded test system on-site. Within a few minutes the poisoning was verified. After administration of HI-6, RBC-AChE activity increased rapidly. Blood samples were reanalysed in our laboratory in Munich. Almost identical course of the AChE activities was recorded by both systems.

The more comprehensive cholinesterase status was determined in Munich. Oxime administration can be stopped when $\mathrm{AChE}$ is aged completely, but has to be continued as long as poison is present in the body and reactivation is possible.

To aid the on-site physician in optimising diagnosis and treatment, a fielded test system should be available to allow rapid determination of the complete cholinesterase status.
\end{abstract}

KEY WORDS: human poisoning, nerve agents, neuromuscular transmission, oxime therapy, pesticides

Organophosphorus compounds are widely used for pest control in agriculture. Poisoning is frequent, especially in developing countries, due to suicide attempts and accidents with more than 200,000 deaths per year worldwide. Among the organophosphorus compounds, nerve agents are a subgroup with high toxicity for humans. The terrorist use of Sarin and VX in Japan (1) has shown the world that nerve agents are no longer restricted to chemical battlefields, but are a pertinent threat for civilian

\footnotetext{
* Partly presented at the EUROTOX 2006/6 CTDC Congress - Symposium on Molecular Mechanisms of Organophosphates, Cavtat, Croatia, 20-24 September 2006.
} 
and military populations. Consequently, effective therapeutic preparedness is mandatory. Inhibition of acetylcholinesterase (AChE, EC 3.1.1.7) is regarded as the primary mechanism for the acute toxicity of all organophosphorus compounds (OP), nerve agents as well as pesticide OP, and therefore should be an integral part of casualty diagnosis and treatment. Therapeutic strategies are directed to competitively antagonise overstimulation of muscarinic receptors by antimuscarinics such as atropine, and to reverse AChE inhibition by reactivation with oximes, e.g. pralidoxime or obidoxime. The latter approach is crucial within neuromuscular synapses where atropine fails, since peripheral neuromuscular block eventually leads to respiratory failure. A lot of research has been performed over the last several decades, leading to a better understanding of individual reactions during and after inhibition [aging, spontaneous reactivation, oxime induced reactivation, formation of phosphoryloximes and their interactions; for review see (2)]. It can be concluded that all of these reactions must be considered for the optimal treatment of poisoned patients.

\section{DEVELOPMENT OF AN OPTIMAL TREATMENT REGIMEN}

Treatment of signs and symptoms due to overstimulation of muscarinic receptors

Typical signs and symptoms of cholinergic crisis develop in direct correlation with the degree of acetylcholinesterase inhibition (3). In severe poisoning, respiratory depression, bronchospasm, bronchosecretion and weakness of the respiratory muscles call for immediate endotracheal suctioning and artificial ventilation. Generally, treatment with muscarinic receptor antagonists, e.g. atropine should achieve heart rate between 80 and 100 beats per minute, the absence of rales during auscultation, and skin dryness (axilla). Furthermore, frequent circulatory insufficiency may call for treatment with catecholamines to increase and maintain blood pressure (i.e. arterial mean pressure above $60 \mathrm{~mm} \mathrm{Hg}$ with systolic pressure exceeding $100 \mathrm{~mm} \mathrm{Hg}$ ) as well as heart rate. In the later phase of severe poisoning, rales might be the result of cardiac insufficiency or (aspiration) pneumonia accompanied by elevated temperature and sweating, thus preventing the use of these parameters as clear indicators of atropine demand. In conclusion, in the acute phase of poisoning, atropine dosing should follow a protocol guaranteeing an early sufficient atropinisation. Such protocols are proposed in modern literature $(4,5)$, recommending a starting dose of $2 \mathrm{mg}$ i.v. followed by an observation period of $5 \mathrm{~min}$. If there is no effect, this dose may be doubled every 5 min to 10 min until muscarinic symptoms subside. With the 5th dose in this regimen, $62 \mathrm{mg}$ of atropine would be administered, an amount that should suffice. For the ongoing treatment, especially at intensive care units, the whole clinical picture has to be considered and dosing of atropine should be performed with caution (e.g. $1 \mathrm{mg} \mathrm{h}^{-1}$ to $4 \mathrm{mg} \mathrm{h}^{-1}$ ) to avoid adverse effects.

\section{Reactivation of acetylcholinesterase}

As atropine is not able to counteract signs and symptoms caused by the overstimulation of nicotinic receptors, especially at neuromuscular endplates, the concept of reactivation of inhibited AChE was developed (6), and pralidoxime (7) and obidoxime (8) were introduced into clinical therapy fifty years ago. Since the sixties, textbooks recommend $4 \mu \mathrm{g} \mathrm{mL}^{-1}$ of oxime as the effective therapeutic concentration. This recommendation is based on a study in cats poisoned by a sarin analogue and then treated with pralidoxime. The result from this investigation "... plasma concentrations of about $2 \times 10-5 \mathrm{~mol} \mathrm{~L}^{-1}$ $\left(4 \mu \mathrm{g} \mathrm{mL}^{-1}\right)$ were needed to counteract neuromuscular block, bradycardia, hypotension and respiratory failure ..." (9) was extrapolated without critical evaluation for treatment of any OP-type-poisoning, using any oxime, and in any species. However, various OPs show quite different properties in reacting with $\mathrm{AChE}(10)$ and reactivation depends both on the properties of the OP-AChE conjugates and of the oxime used $(2,11)$. Moreover, enormous differences between species have to be considered (12). Based on reaction constants derived from experiments with human RBC-AChE, reasonable plasma concentrations of oximes for reactivation of insecticide as well as nerve agentinhibited AChE can be calculated (2, 11, 13-19). Results indicate that AChE inhibited by most nerve agents and insecticide OPs can be reactivated with obidoxime at a plasma concentration of approximately $10 \mu \mathrm{mol} \mathrm{L}^{-1}$. This plasma concentration can be adjusted by an i.v. bolus dose of $250 \mathrm{mg}$, followed by $750 \mathrm{mg}$ of obidoxime per day. In actual emergency situations, this regimen proved effective in reactivating AChE inhibited by insecticide OP $(11,16,20)$. 
Comparably, Pawar (21) showed reduced morbidity and mortality in moderately severe insecticide OPpoisoned patients treated with effective doses of pralidoxime $(2 \mathrm{~g}$ loading dose, followed by $24 \mathrm{~g}$ per day). Hence, effective oximes should be administered in appropriate dosage as early as possible (e.g. by autoinjectors or i.v.) and effective concentrations should be maintained as long as reactivation is possible. The treatment period may be shortened to several hours in poisoning with $\mathrm{OP}$ where toxic concentrations persist only for a very short time in the body (e.g. sarin) or when OP-AChE-conjugates age quickly (e.g. soman). In contrast, in poisoning with persisting nerve agents (e.g. VX) or after ingestion of huge amounts of poison as frequently found in suicide poisoning, administration of oximes may be necessary for several days.

\section{MONITORING OF THE CHOLINESTERASE STATUS}

Assessment of therapeutic effectiveness in OPpoisoned patients is difficult due to a wide variety of therapeutic measures taken at intensive care units (e.g. artificial ventilation, sedation). To monitor the course of poisoning in OP-poisoned patients, a laboratory test system, called cholinesterase status, was developed $(16,22)$ and used in intensive care units (Figure 1) $(11,20,23,24)$. The cholinesterase status consisted of:

- Red blood cell (RBC)-AChE activity: Blood was immediately diluted bed-side 1:100 (v/v) with ice-cold phosphate-buffer $\left(0.1 \mathrm{~mol} \mathrm{~L}^{-1}, \mathrm{pH}\right.$ 7.4; $0.03 \%$ Triton X-100). AChE activity was determined according to a modified Ellman method (22). Reactivatability of RBC-AChE activity was assessed by incubation of diluted blood samples with $0.1 \mathrm{mmol} \mathrm{L}^{-1}$ obidoxime at $37^{\circ} \mathrm{C}$ for 30 min (22).

- Inhibitory material, indicating the presence of active poison in the body without its exact identification: Plasma of patients was incubated with standardized RBC-AChE obtained from a healthy donor at $37^{\circ} \mathrm{C}$ for $1 \mathrm{~h}$. Thereafter the RBC-AChE activity was measured according to the modified Ellman method (22). Plasma butyrylcholinesterase (BChE; EC 3.1.1.8) activity was determined by the Ellman method with some minor modifications using $1.0 \mathrm{mmol} \mathrm{L}^{-1}$

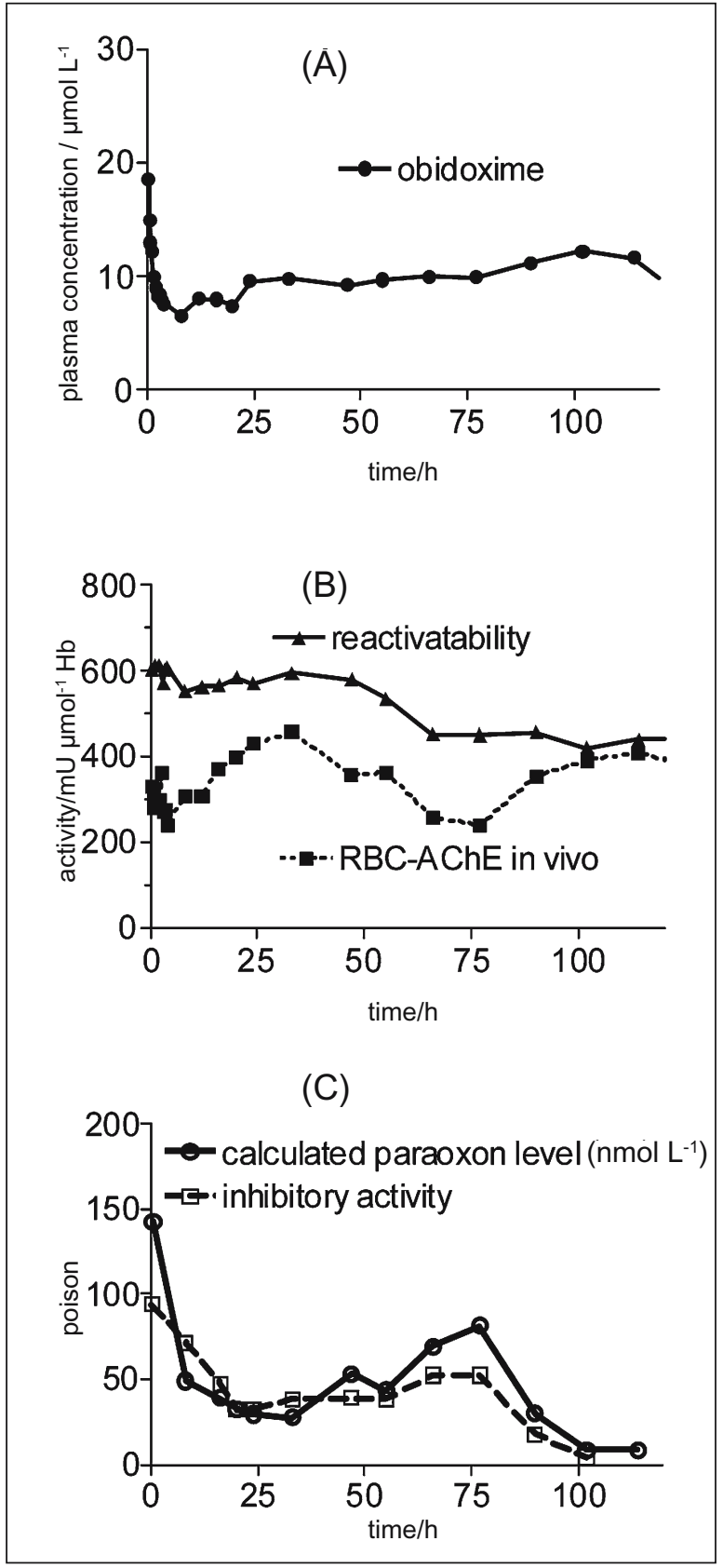

Figure 1 Cholinesterase status of a patient with parathion poisoning. Obidoxime plasma concentration was determined by HPLC according to Spoehrer at al. (46) (upper panel, A). RBC-AChE activity (mid panel $B$; triangles, full line) and reactivatability (mid panel B; squares, hatched line) were determined according to a modified Ellman method. Inhibitory activity (\%) was estimated as AChE activity of donor RBCs incubated with the patient's plasma (lower panel, C; open squares, hatched line); and paraoxon (nmol $L^{-1}$ ) calculated from RBC-AChE activity, reactivatability and obidoxime plasma concentration using the respective reaction constants (lower panel, C; open circles, full line) (29).

butyrylthiocholine as substrate (22).

Determination of the cholinesterase status is possible in our laboratory by using an automated 
system with a capacity to perform 600 assays per day $(25,26)$. Furthermore, for determination of RBC$\mathrm{AChE}$ and plasma $\mathrm{BChE}$ an improved portable device, appropriate for the use in the field was developed (27).

To demonstrate the properties of cholinesterase status, a case report of parathion poisoning is presented here [compare $(28,29)]$. This example resembles a course of poisoning that might be expected in percutaneous intoxication with a persisting OP such as VX. A 45-year-old man ingested about $100 \mathrm{~mL}$ of a parathion-containing solution. On presentation to the emergency physician, the patient was unconscious with severe signs and symptoms of cholinergic crisis. After administration of $1.5 \mathrm{mg}$ of atropine the patient was intubated and artificial ventilation was initiated. At the local hospital gastric lavage was performed and the patient was stabilized. After treatment with 2 bolus doses of obidoxime and atropine infusion, the patient was transferred to the intensive care unit of the toxicological department of the $2^{\text {nd }}$ Medical Clinic, Technical University, Munich. Here, the obidoxime regimen was started $(250 \mathrm{mg}$ i.v. bolus, followed by $750 \mathrm{mg}$ per day), maintaining the therapeutic plasma level of about $10 \mu \mathrm{mol} \mathrm{L}^{-1}$ obidoxime (Figure 1, A, upper panel). Due to the persisting poison load, only partial reactivation of RBCAChE could be achieved over approximately four days. During this period, very little aging occurred (Figure 1, B, mid panel) and BChE remained completely inhibited. When the poison load significantly decreased on the fourth day following initiation of the obidoxime regimen, complete $\mathrm{AChE}$ reactivation was achieved. Furthermore, based on RBC-AChE activity, reactivatability and obidoxime plasma concentration, a paraoxon concentration necessary for such a degree of inhibition could be calculated (29) by using the respective reaction constants (17). The time course of this theoretical curve closely fits the actual time course of inhibitory activity, as determined in the poisoned patient (Figure 1, C, lower panel).

In cases of exposure to nerve agents, early determination of RBC-AChE is mandatory to confirm clinical diagnosis without sophisticated verification of the agent used. For this purpose, the Test Mate ${ }^{\circledR}$ was developed by EQM research (27). The device was tested in an international NBC-defence exercise (Precise Response 2006, Canada). During the training scenario, the diagnostic group of the German Medical-Chemical Task Force entered a chemical agent environment for treatment of victims of a terrorist attack. An anesthetized pig poisoned with sarin emulated a poisoned patient. On arrival, the pig ( $20 \mathrm{~kg})$ displayed typical clinical signs of cholinergic crisis; salivation, miosis and dyspnoea. Using the Test-Mate ${ }^{\circledR}$ system marked inhibition of $\mathrm{AChE}$ verified poisoning with a cholinesterase inhibitor within a few minutes. After administration of the oxime HI-6 (260 mg) in combination with atropine $(0.6 \mathrm{mg})$ (bolus dose), a rapid increase in RBC-AChE activity was recorded on site. This was clearly accompanied by prompt clinical improvement, indicating the effectiveness of the oxime treatment. To simulate the situation following rescue and decontamination, two additional pigs were poisoned with sarin and treated at a field intensive care unit. Here, HI- 6 or obidoxime were administered in combination with atropine. As observed in the field, the clinical situation improved after oxime treatment, however repetitive atropine doses were necessary to counteract hypersalivation. In one pig, diazepam was also required due to convulsions. These animals were maintained under anaesthetic for approximately two hours, during which time their blood was sampled. RBC-AChE activity as well as plasma $\mathrm{BChE}$ activity were determined on site to monitor the course of treatment. In addition, blood samples were sent to our laboratory in Munich and were reanalysed with an automated analysis system (Tecan RMP). Comparison of the results showed almost identical values independent of the analytic system used (Figure 2, upper panel).

\section{INVESTIGATION OF NEUROMUSCULAR TRANSMISSION}

Investigations on muscle strips of various species revealed that oximes were able to restore force to muscles paralysed by OP; however, several therapeutic gaps (e.g. soman) still exist (30-36). Aside from an unknown direct oxime reaction, recovery of muscle force was mainly attributed to the reactivation of inhibited muscle AChE. A series of experiments on phrenic nerve-diaphragmpreparations of mice circumfused with paraoxon showed that obidoxime restored muscle force, and this was clearly accompanied by an increase in muscle AChE activity (36). Comparably, in patients with insecticide OP-poisoning, it was reported that low RBC-AChE activity $(<10 \%)$ was associated with marked decrement-phenomena (23) (stimulation 


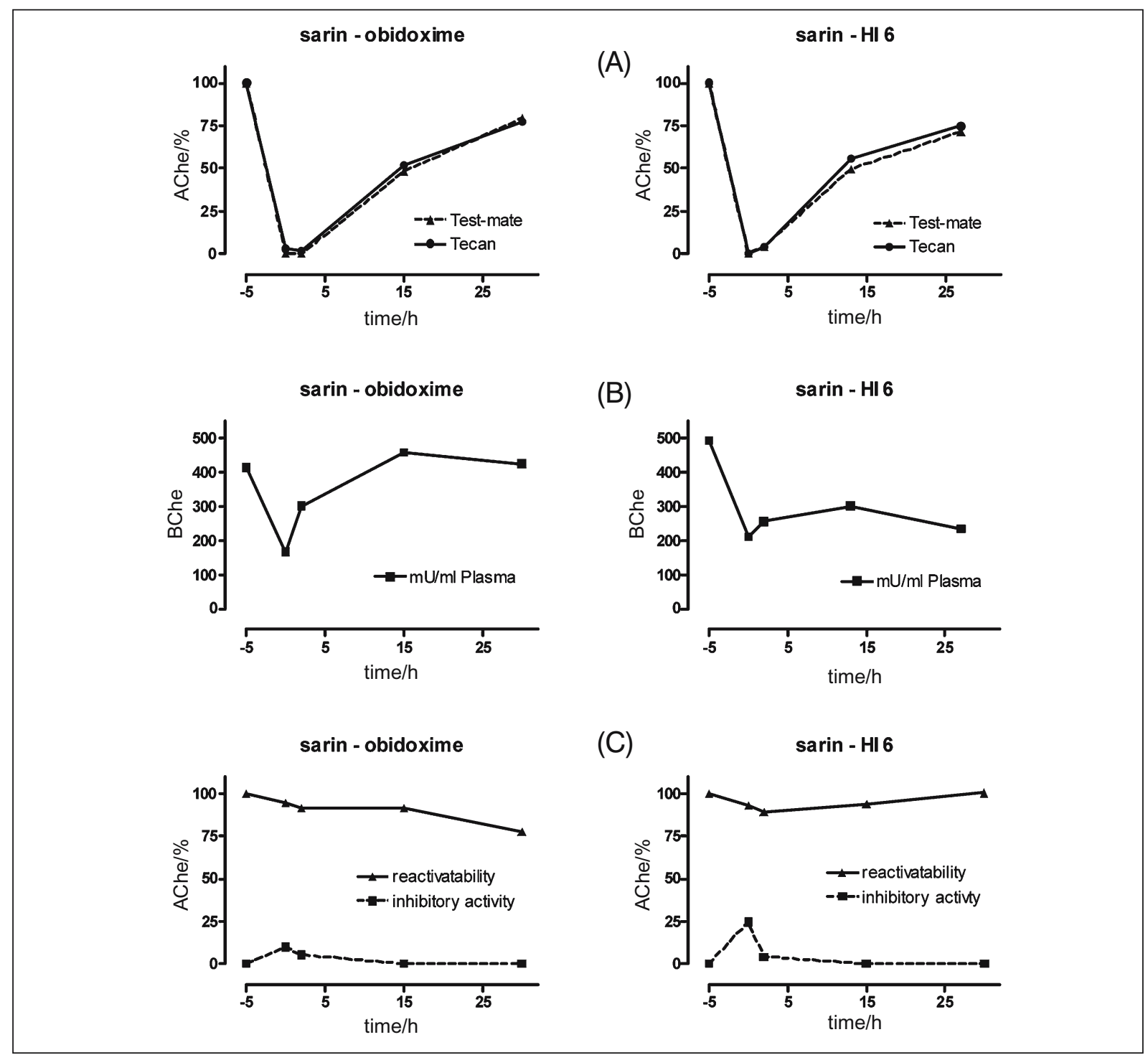

Figure 2 Cholinesterase activity, reactivatability and inhibitory material determined in pig blood samples following sarin exposure. During the NBC-defence exercise Precise Response 2006 in Canada, anaesthetized pigs were poisoned with sarin and treated with HI-6 or obidoxime. After the poisoning, (A) RBC-AChE was determined on-site with the Test Mate ${ }^{\circledR}$ system and then with an automated system (Tecan) at the Bundeswehr Institute of Pharmacology and Toxicology in Munich. Additionally, (B) BChE in plasma $(\mathrm{m} U / \mathrm{ml})$, (C) reactivatability of $R B C-A C h E$ and inhibitory activity (of compounds in plasma) were determined in Munich.

of a nerve with frequencies of $30 \mathrm{~Hz}$ to $50 \mathrm{~Hz}$ and recording of compound action potentials), indicating severe disturbance of neuromuscular transmission and urgent requirement of artificial ventilation (37, 38). At RBC-AChE activity of about $15 \%$ to $20 \%$ mainly decrement-increment-phenomena occurred (23). This type of response is typically found in moderate to severe poisoning $(37,38)$, presumably also indicating the need for artificial ventilation. At RBC-AChE activity above $30 \%$, little disturbance of neuromuscular transmission could be detected (23). $\mathrm{AChE}$ is encoded on a single gene in mammalian species (39), and therefore a similar structure may be assumed to occur throughout the body $(2,40,41)$. Consequently, RBC-AChE should have comparable functional properties to synaptic $\mathrm{AChE}$ and therefore may be used as surrogate parameter, reflecting the AChE status at the synaptic site. However, when RBC-AChE ages completely, restoration takes several months (42) while synaptic AChE recovers faster (43, 44). Therefore, under these conditions, RBC-AChE can no longer be regarded as a suitable parameter to indicate the end of the cholinergic crisis. As BChE may show quite different properties concerning inhibition by OPs as well as reactivation of the inhibited enzyme by oximes $(2,45)$, this parameter has to be used 
with caution. Under such conditions, investigation of neuromuscular transmission may be of help. Especially when ventilators are in limited supply, e.g. mass casualties with rapidly aging $\mathrm{OP}$, investigation of neuromuscular transmission could guide the physician whether artificial ventilation is necessary.

\section{RECOMMENDATION FOR DIAGNOSIS AND TREATMENT OF PATIENTS POISONED BY ORGNOPHSPHORUS COMPOUNDS}

RBC-AChE activity should be determined as early as possible to confirm the diagnosis of poisoning by inhibitors of cholinesterase.

Atropine should be given according to clinical signs and symptoms using a regime which ensures fast atropinisation without overdosing, e.g. doubling the doses every 5 min after a starting dose with $2 \mathrm{mg}$.

Effective oximes should be administered at appropriate doses as early as possible to OP-poisoned patients.

The effects of oximes may be assessed using the cholinesterase status, thus allowing optimal oxime treatment; oximes should be administered as long as reactivation is possible and inhibitory material is present in the patient. Investigation of the neuromuscular transmission should complete the monitoring system as objective clinical parameter. Especially when RBC-AChE activity ages completely, improvement of neuromuscular transmission may be the decisive parameter to indicate the end of the cholinergic crisis. This item urgently needs further investigation.

To aid the on-site physician in optimizing diagnosis and treatment, field test systems should be further advanced to allow for rapid determination of the extended cholinesterase status.

\section{Acknowledgement}

The authors are grateful to M. Radtke, B. Pfeiffer and $M$. Pusch for their skilful and engaged technical assistance.

\section{REFERENCES}

1. Tu AT. Chemical terrorism: horrors in Tokyo subway and Matsumoto city. Fort Collins: Alaken Inc.; 2002.

2. Eyer P. The role of oximes in the management of organophosphorus pesticide poisoning. Toxicol Rev 2003;22:165-90.

3. Lotti M. Clinical toxicology of anticholinesterase agents in humans. In: Krieger RI, editor. Handbook of Pesticide Toxicology. $2^{\text {nd }}$ ed. San Diego, San Francisco, New York, Boston, London, Sydney, Tokyo: Academic Press; 2001. p. 1043-85.

4. Aaron CK, Howland MA. Insecticides: organophosphates and carbamates. In: Goldfrank LR, Flomenbaum NE, Lewin NA, Weisman RS, Howland MA, Hoffman RS, editors. Toxicologic Emergencies. $5^{\text {th }}$ ed. Norwalk, Connecticut: Appleton \& Lange; 1994. p. 1105-16.

5. Eddleston M, Buckley NA, Checketts H, Senarathna L, Mohamed F, Sheriff MH, Dawson A. Speed of initial atropinisation in significant organophosphorus pesticide poisoning--a systematic comparison of recommended regimens. J Toxicol Clin Toxicol 2004;42:865-75.

6. Wilson IB, Ginsburg S. A powerful reactivator of alkylphosphate-inhibited acetylcholinesterase. Biochem Biophys Acta 1955;18:168-70.

7. Namba T, Hiraki K. PAM (Pyridine-2-aldoxime methiodide) therapy for alkylphosphate poisoning. JAMA 1958;166:1834-9.

8. Erdmann WD, Clarmann M. Ein neuer EsteraseReaktivator für die Behandlung von Vergiftungen mit Alkylphosphaten [A new esterase reactivator for the treatment of alkylphosphate poisoning, in German]. Deutsch Med Wochenschr 1963;45:2201-7.

9. Sundwall A. Minimum concentrations of $\mathrm{N}$ methylpyridinium-2-aldoxime methane sulphonate (P2S) which reverse neuromuscular block. Biochem Pharmacol 1961;8:413-7.

10. Worek F, Thiermann H, Szinicz L, Eyer P. Kinetic analysis of interactions between human acetylcholinesterase, structurally different organophosphorus compounds and oximes. Biochem Pharmacol 2004;68:2237-48.

11. Thiermann H, Szinicz L, Eyer F, Worek F, Eyer $P$, Felgenhauer N, Zilker T. Modern strategies in therapy of organophosphate poisoning. Toxicol Lett 1999;107:233-9.

12. Worek F, Reiter G, Eyer P, Szinicz L. Reactivation kinetics of acetylcholinesterase from different species inhibited by highly toxic organophosphates. Arch Toxicol 2002;76:523-9.

13. Eyer P. Optimal oxime dosage regimen, a pharmacokinetic approach. In: Szinicz L, Eyer P, Klimmek R, editors. Role of Oximes in the Treatment of Anticholinesterase Agent Poisoning.Heidelberg. Berlin, Oxford: Spektrum Akademischer Verlag; 1996. p. 33-51.

14. Eyer P. Use of obidoxime in OP poisoning. Hum Exp Toxicol 1996;15:78.

15. Eyer P, Szinicz L, Thiermann H, Worek F, Zilker T. Testing of antidotes for organophosphorus compounds: experimental procedures and clinical reality. Toxicology 2007;233:108-19.

16. Thiermann H, Mast U, Klimmek R, Eyer P, Hibler A, Pfab R, Felgenhauer N, Zilker T. Cholinesterase status, 
pharmacokinetics and laboratory findings during obidoxime therapy in organophosphate poisoned patients. Hum Exp Toxicol 1997;16:473-80.

17. Worek F, Baecker M, Thiermann H, Szinicz L, Mast U, Klimmek R, Eyer P. Reappraisal of indications and limitations of oxime therapy in organophosphate poisoning. Hum Exp Toxicol 1997;16:466-72.

18. Worek F, Szinicz L, Eyer P, Thiermann H. Evaluation of oxime efficacy in nerve agent poisoning: development of a kinetic-based dynamic model. Toxicol Appl Pharmacol 2005;209:193-202.

19. Worek F, Eyer P, Szinicz L, Thiermann H. Simulation of cholinesterase status at different scenarios of nerve agent exposure. Toxicology 2007;233:155-65.

20. Thiermann H, Szinicz L, Eyer P, Felgenhauer N, Zilker T, Worek F. Lessons to be learnt from organophosphorus pesticide poisoning for the treatment of nerve agent poisoning. Toxicology 2007;233:145-54.

21. Pawar KS, Bhoite RR, Pillay CP, Chavan SC, Malshikare DS, Garad SG. Continuous pralidoxime infusion versus repeated bolus injection to treat organophosphorus pesticide poisoning: a randomised controlled trial. Lancet 2006;368:2136-41.

22. Worek F, Mast U, Kiderlen D, Diepold C, Eyer P. Improved determination of acetylcholinesterase activity in human whole blood. Clin Chim Acta 1999;288:7390.

23. Thiermann H, Szinicz L, Eyer P, Zilker T, Worek F. Correlation between red blood cell acetylcholinesterase activity and neuromuscular transmission in organophosphate poisoning. Chem Biol Interact 2005;157-158:345-7.

24. Eddleston M, Eyer P, Worek F, Mohamed F, Senarathna L, von Meyer L, Juszczak E, Hittarage A, Azhar S, Dissanayake W. Differences between organophosphorus insecticides in human self-poisoning: a prospective cohort study. Lancet 2005;366:1452-9.

25. Pfeiffer B. Vergiftungen durch Organophosphate I. MTA Dialog 2005;6:583-5.

26. Pfeiffer B. Analyzing cholinesterase in organophosphate poisoning. Tecan J 2006;2:22-3.

27. Eberly JP, Eyer P, Pfeiffer B, Szincz L, Worek F. Modification of the Test-mate ChE cholinesterase test system for use over an extended temperature range. Medical Defense Bioscience Review 2004;1-11.

28. Eyer F, Meischner V, Kiderlen D, Thiermann H, Worek F, Haberkorn M, Flegenhauer N, Zilker T, Eyer P. Human parathion poisoning. Toxicol Rev 2003;22:143-63.

29. Eyer F, Eyer P. Enzyme-based assay for quantification of paraoxon in blood of parathion poisoned patients. Hum Exp Toxicol 1998;17:645-51.

30. Wolthuis O, Vanwersch RA, van der Wiel HJ. The efficacy of some bis-pyridinium oximes as antidotes to soman in isolated muscles of several species including man. Eur J Pharmacol 1981;70:355-69.

31. Smith AP, van der Weil HJ, Wolthuis OL. Analysis of oxime-induced neuromuscular recovery in guinea-pig, rat and man following soman poisoning in vitro. Eur $\mathrm{J}$ Pharmacol 1981;70:371-9.
32. van der Meer $\mathrm{C}$, Wolthuis OL. The effect of oximes on isolated organs intoxicated with organophosphorus anticholinesterases. Biochem Pharmacol 1965; 14:1299-312.

33. van Helden $H P$, van der Wiel $H J$, Wolthuis OL. Retention of soman in rats, guinea-pigs and marmosets: speciesdependent effects of the soman simulator, pinacolyl dimethylphosphinate (PDP). J Pharm Pharmacol 1988;40:35-41.

34. van Helden HP, van der Wiel HJ, de Lange J, Busker RW, Melchers BP, Wolthuis OL. Therapeutic efficacy of HI-6 in soman-poisoned marmoset monkeys. Toxicol Appl Pharmacol 1992;115:50-6.

35. Alberts P. A new $\mathrm{H}$-oxime restores rat diaphragm contractility after esterase inhibition in vitro. Eur $\mathrm{J}$ Pharmacol 1990;184:191-4.

36. Thiermann H, Eyer P, Worek F, Szinicz L. Effects of oximes on muscle force and acetylcholinesterase activity in isolated mouse hemidiaphragms exposed to paraoxon. Toxicol 2005;214:190.

37. Maselli RA, Leung C. Analysis of anticholinesteraseinduced neuromuscular transmission failure. Muscle Nerve 1993;16:548-53.

38. Besser R, Gutmann L, Dillmann U, Weilemann LS, Hopf $\mathrm{HC}$. End-plate dysfunction in acute organophosphate intoxication. Neurology 1989;39:561-7.

39. Massoulie J, Pezzementi L, Bon S, Krejci E, Vallette FM. Molecular and cellular biology of cholinesterases. Prog Neurobiol 1993;41:31-91.

40. Brimijoin S. Molecular forms of acetylcholinesterase in brain, nerve and muscle: nature, localization and dynamics. Prog Neurobiol 1983;21:291-322.

41. Mortensen SR, Brimijoin S, Hooper MJ, Padilla $\mathrm{S}$. Comparison of the in vitro sensivitiy of rat acetylcholinesterase to chlorpyrifos-oxon: What do tissue IC50 values represent? Toxicol Appl Pharmacol 1998;148:46-9.

42. Namba T, Nolte CT, Jackrel J, Grob D. Poisoning due to organophosphate insecticides. Acute and chronic manifestations. Am J Med 1971;50:475-92.

43. Brank M, Zajc-Kreft K, Kreft S, Komel R, Grubic $Z$. Biogenesis of acetylcholinesterase is impaired, although its mRNA level remains normal, in the glucocorticoid-treated rat skeletal muscle. Eur $\mathrm{J}$ Biochem 1998;251:374-81.

44. Grubic Z, Sketelj J, Klinar B, Brzin M. Recovery of acetylcholinesterase in the diaphragm, brain, and plasma of the rat after irreversible inhibition by soman: a study of cytochemical localization and molecular forms of the enzyme in the motor end plate. $\mathrm{J}$ Neurochem 1981;37:909-16.

45. Worek F, Eyer P, Szinicz L. Inhibition, reactivation and aging kinetics of cyclohexylmethylphosphonofluoridateinhibited human cholinesterases. Arch Toxicol 1998;72:580-7.

46. Spöhrer U, Eyer P. Separation of geometrical syn and anti isomers of obidoxime by ion-pair highperformance liquid chromatography. J Chromatogr A 1995;693:55-61. 


\section{Sažetak}

\section{ACETILKOLINESTERAZA U ERITROCITIMA I BUTIRILKOLINESTERAZA U PLAZMI - VAŽNI POKAZATELJI ZA LIJEČENJE OSOBA OTROVANIH ORGANOFOSFORNIM SPOJEVIMA}

Inhibicija acetilkolinesteraze (AChE) smatra se primarnim mehanizmom toksičnoga djelovanja organofosfornih spojeva (OP). Strategije liječenja idu za zaustavljanjem prekomjerne stimulacije muskarinskih receptora atropinom i reaktiviranjem inhibiranog AChE oksimima. Ključna je reaktivacija u neuromuskularnoj sinapsi, u kojoj atropin nije djelotvoran, budući da neuromuskularna blokada u konačnici vodi do prestanka disanja. Važno je što ranije prepoznati otrovanje organofosfornim spojem.

U jednoj međunarodnoj vježbi zaštite od nuklearnog, biološkog i kemijskog napada svinje pod anestezijom otrovane su sarinom te liječene atropinom i oksimom. Uzeti su im uzorci krvi te s pomoću terenskoga testa na licu mjesta određena aktivnost AChE u eritrocitima. Otrovanje je potvrđeno za nekoliko minuta. Nakon primjene HI-6, aktivnost AChE brzo je porasla. Isti su uzorci krvi ponovno analizirani u našem laboratoriju u Münchenu. Oba su testa zabilježila gotovo istovjetan tijek aktivnosti AChE. U Münchenu je međutim napravljen potpuniji nalaz kolinesteraza. Liječenje oksimima može se prekinuti kada AChE potpuno "ostari" (tj. dealkilira), ali ga valja nastaviti dokle god je otrov u tijelu, a reaktivacija moguća.

Liječnici na terenu trebali bi raspolagati terenskim testovima radi brzoga i potpunog utvrđivanja statusa kolinesteraza, a time i kvalitetnije dijagnoze.

KLJUČNE RIJEČI: liječenje oksimima, neruni agensi, neuromuskularni prijenos, otrovanje ljudi, pesticidi

\section{CORRESPONDING AUTHOR:}

Dr. Horst Thiermann

Bundeswehr Institute of Pharmacology and Toxicology

Neuherbergstr. 11

D-80937 Munich, Germany

Email: HorstThiermann@bundeswehr.org 